\title{
АПРОКСИМАЦІЯ УНІВЕРСАЛЬНИХ ХАРАКТЕРИСТИК ГІДРОТУРБІН МЕТОДАМИ ІНЖЕНЕРНОЇ ГЕОМЕТРІЇ
}

П.Ф. Васько, д-р техн. наук

Інститут відновлюваної енергетики НАН України, 02094, вул. Гната Хоткевича, 20А, м. Київ, Україна.

Апробовано застосування методів інженерної геометрї для апроксимації функціональних двопараметричних залежностей універсальних характеристик гідротурбін, які являють собою сукупність розімкнених та зімкнених ліній на площині, щео характеризують результати експериментальних досліджень фізичних моделей турбін. Універсальні характеристики наведені в номенклатурі гідротурбін $і$ слугують вихідною інформачією для вибору параметрів натурних зразків та визначення режимів їх ефективної експлуатаџії. Вони дозволяють розрахувати діаметр робочого колеса для отримання заданої потужності; номінальне число обертів турбіни; значення ККД і допустимі висоти відсмоктування при всіх напорах i потужностях; відкриття напрямного апарату для будь-якого навантаження турбіни. Проведення багатоваріантних розрахункових досліджень потребує цифрового оброблення вихідної графічної інформації та ії подальшого використання. Тому були розглянуті питання апроксимаџії кривих та поверхні кубічними сплайн-функиіями, графічного визначення максімори поверхні та графічного визначення перетину поверхонь. Розроблено методичні положення визначення енергоефективного режиму роботи пропелерних та радіально-осьових гідротурбін при змінних витратах води та частоти обертання. Положення трунтуються на застосуванні методів інженерної геометрї для апроксимації універсальної характеристики турбіни у формі поверхні тривимірного геометричного тіла та визначення максімори поверхні, яка характеризує оптимальну функціональну залежність між відкриттям напрямного апарату $і$ частотою обертання, щзо забезпечує найбільиу енергетичну ефективність прочесу перетворення гідроенергетичного потенціалу водотоку в механічну енергію обертового руху турбіни. Запропоновано алгоритм розрахунку коефіцієнтів апроксимаційних кубічних сплайнфункиій універсальної характеристики гідротурбіни для визначення та реалізації законів керування енергоефективними режимами роботи гідроагрегатів при одночасній зміні двох параметрів керування. Алгоритм полягає в апроксимації вихідної універсальної характеристики гідротурбіни на рівномірну сітку параметрів керування з подальшим прямим розрахунком коефіцієнтів сплайн-функцій за рекурентними співвідношеннями. Бібл. 17, рис. 7.

Ключові слова: гідротурбіна, апроксимація, лінія, поверхня, сплайн, характеристика.

\section{APPROXIMATION OF UNIVERSAL CHARACTERISTICS OF HYDROTURBINES BY ENGINEERING GEOMETRY METHODS}

P. Vasko, doctor of technical science

Institute of Renewable Energy, NAS of Ukraine,

02094, St. Hnata Khotkevycha, 20A, Kyiv, Ukraine.

The application of engineering geometry methods for approximation of functional two-parameter dependences of universal characteristics of hydroturbines, which are a set of open and closed lines on the plane, which characterize the results of experimental studies of physical models of turbines, is tested. Universal characteristics are given in the nomenclature of hydroturbines and serve as initial information for a choice of parameters of full-scale samples and definition of modes of their effective operation. They allow you to calculate the diameter of the impeller to obtain a given power; nominal turbine speed; values coefficient of performance and allowable suction heights at all pressures and capacities; opening of the directing device for any loading of the turbine. Conducting multivariate computational research requires digital processing of the original graphical information and its further use, so the issues of approximation of curves and surfaces by cubic spline functions, graphical determination of surface maxima, graphical determination of surface cross section were considered. Methodical provisions for determining the energy-efficient mode of operation of propeller (C) П.Ф. Васько, 2021 
and radial-axial hydraulic turbines at variable water flow rates and speed have been developed. The provisions are based on the application of engineering geometry methods to approximate the universal characteristics of the turbine in the form of the surface of a three-dimensional geometric body and determine the surface maxima, which characterizes the optimal functional relationship between the opening of the guide and speed and provides maximum energy turbines. An algorithm for calculating the coefficients of approximation cubic spline functions of the universal characteristic of a hydroturbine for determining and implementing the laws of control of energy-efficient modes of operation of hydraulic units with simultaneous change of two control parameters is proposed. The algorithm consists in approximating the initial universal characteristic of the hydroturbine to a uniform grid of control parameters with the subsequent direct calculation of coefficients of spline functions on recurrent relations. Bibl.. 17, fig. 7.

Keywords: hydroturbine, approximation, line, surface, spline, characteristic.

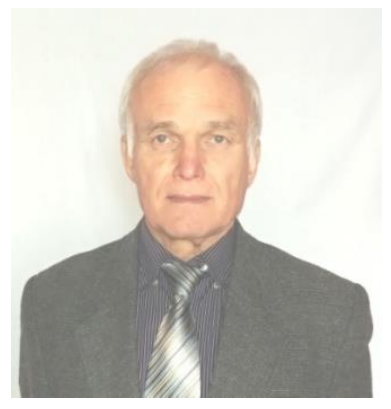

П.Ф. Васько P.Vasko
Відомості про автора: доктор технічних наук за спеціальністю «Перетворення відновлюваних видів енергії», завідувач відділу гідроенергетики Інституту відновлюваної енергетики НАНУ.

Освіта: Національний технічний університет України «Київський політехнічний інститут», інженер-електромеханік.

Наукова сфера: альтернативна енергетика, енергозбереження, перетворення відновлюваних видів енергії, мала гідроенергетика

Публікації: 257.

ORCID: 0000-0001-8807-7173.

Контакти: тел./факс: +38(044)206-28-09

e-mail: hydro@ive.org.ua
Author information: doctor of technical sciences majoringin «Renewable Energy Transformation», Head of Hydropower Department of the Institute of Renewable Energy NAS of Ukraine.

Education: National Technical University of Ukraine «Kyiv Polytechnic Institute»,

Electrician Engineer.

Research area: alternative energy, energy saving, conversion of renewable energy, small hydropower.

Publications: 257

ORCID: 0000-0001-8807-7173.

Contacts: phone/fax: +38(044)206-28-09, e-mail: hydro@ive.org.ua
Перелік використаних позначень та скорочень:

ККД-коефіцієнт корисної дії;

ГЕС-гідроелектрична станція;

$\left(Q^{l}\right)$ - зведена витрата води;

$\left(n^{l}\right)$ - зведена частота обертання;

$\alpha_{o}$ - відкриття напрямного апарату;

\section{Вступ. Універсальні характеристики} слугують основним документом, на підставі якого здійснюється вибір всіх параметрів проєктованих турбін та оцінка їх енергетичних властивостей. Вони визначають залежність коефіцієнта корисної дії (ККД), критичного кавітаційного коефіцієнта, відкриття напрямного апарата і кута встановлення лопатей робочого колеса гідравлічної турбіни від зведених витрат і частот обертання гідравлічної турбіни. Зведені витрата i частота обертання характеризують гідравлічну турбіну 3 робочим колесом діаметром 1 м та напором 1 м [1].

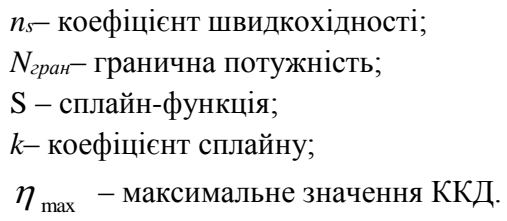

Взаємний зв'язок між ККД (ๆ), зведеними витратами $\left(Q^{l}\right)$ і зведеними числами обертів $\left(n^{l}\right)$ графічно зображується у вигляді сімейства кривих постійних значень ККД у координатах площини $\left(Q^{l}, n^{l}\right)$. Також на цій площині наносяться криві постійних значень відкриття лопатей напрямного апарата $\alpha_{o}$, коефіцієнта швидкохідності $n_{s}$, криві

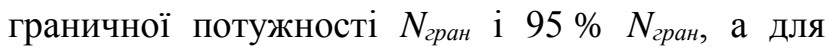
поворотно-лопатевих турбін, крім того, і криві кутів встановлення лопатей робочого колеса (рис.1). 


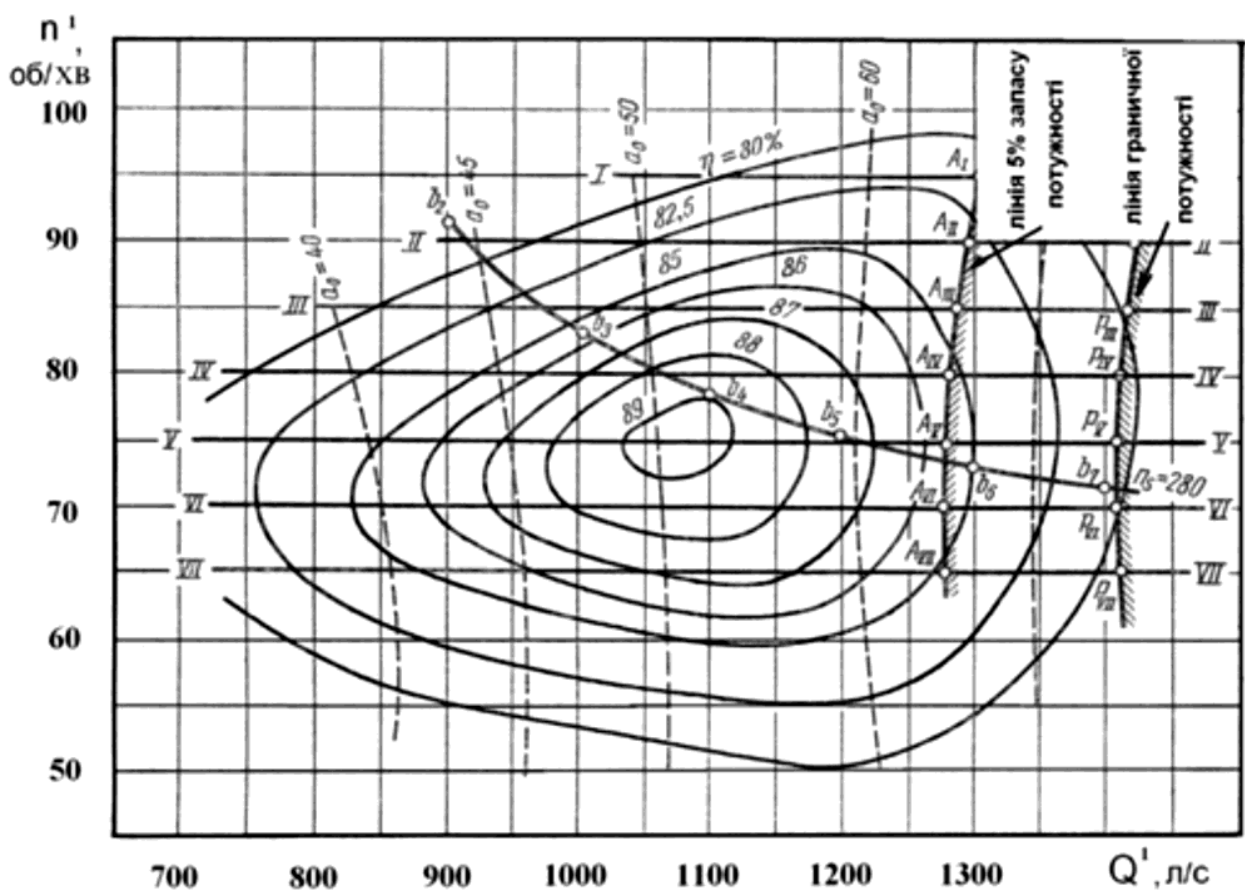

Рис. 1. Зразок графічного зображення універсальної характеристики гідротурбіни

Fig. 1.Sample graphic image of the universal characteristics of the turbine

Універсальні характеристики наведені в номенклатурі гідротурбін і слугують вихідною інформацією для вибору параметрів натурних зразків та визначення режимів їх ефективної експлуатації. Вони дозволяють розрахувати діаметр робочого колеса для отримання заданої потужності; номінальне число обертів турбіни; значення ККД і допустимі висоти відсмоктування при всіх напорах i потужностях; відкриття напрямного апарату для будь-якого навантаження турбіни, а для поворотно-лопатевих турбін також кут встановлення лопатей робочого колеса $[2,3]$. Проведення багатоваріантних розрахункових досліджень потребує цифрового оброблення вихідної графічної інформації та іiї подальшого використання, яке може бути ефективно реалізовано шляхом застосування методів інженерної геометрії $[4,5]$, зокрема сплайнапроксимації кривих та поверхні [6,7], графічного визначення максімори поверхні [8,9], графічного визначення перетину поверхонь [10].
Мета роботи полягає в апробації застосування алгоритмів геометричного моделювання для апроксимації функціональних двопараметричних залежностей універсальних характеристик гідротурбін.

\section{Вихідні положення. Основою} геометричного моделювання є системи рівнянь, що описують форму геометричних об'єктів та їх рух. Все різноманіття можливих форм об'єктів може бути представлено комбінацією простих фігур, які складаються з точок, ліній та поверхонь [8]. Сьогодні геометричне моделювання широко застосовується в проєктуванні [4-7]. Розроблені методи і алгоритми інженерної геометрії можуть бути використані також для аналізу числових даних, якщо їм надати геометричну інтерпретацію. Оскільки універсальна характеристика (рис.1) являє собою сукупність розімкнених та зімкнених ліній на площині, що характеризують результати експериментальних досліджень фізичних моделей турбін, то для їх 
аналізу апріорі може бути застосовано геометричне моделювання.

\section{Формулювання геометричних задач.}

Спершу розглянемо геометричну інтерпретацію результатів експериментальних досліджень, представлених на універсальній характеристиці розімкненими лініями. На рис. 1 до них належать сімейство кривих зі сталими значеннями відкриття напрямного апарату $\alpha_{o}$ та, як зразок, одна крива зі сталим значенням коефіцієнта швидкохідності $n_{s}$. На повномасштабних універсальних характеристиках наводяться також сімейство кривих $n_{s}$ та аналогічне сімейство кривих зі сталими значеннями кута повороту лопатей робочого колеса турбіни. Тому подальше викладення матеріалу щодо апроксимації розімкнених ліній виконаємо на прикладі кривих $\alpha_{o}$.

Кожна $i$-ma крива $\alpha_{o i}$ являє собою ізолінію, що складається 3 точок, які відповідають одному значенню відкриття напрямного апарата

$$
\alpha_{o i}=f_{i}\left(Q^{1}, n^{1}\right)=\text { const, } i=1,2,3, \ldots, \mathrm{I} .
$$

Сукупність ізоліній (1) може бути апроксимована неперервною поверхнею

$$
\alpha_{o}=f\left(Q^{1}, n^{1}\right),
$$

проєкція якої на площину $\left(Q^{l}, n^{l}\right)$ також може бути представлена новою сукупністю ізоліній 3 довільною дискретністю між лініями для подальшого використання

$$
\alpha_{o j}=f_{j}\left(Q^{l}, n^{l}\right)=\text { const, } \boldsymbol{j}=1,2,3, \ldots, \mathrm{J} \text {. }
$$

За функціонування гідротурбіни зі змінними характеристиками водотоку незалежними параметрами керування слугують відкриття напрямного апарата, кут повороту лопатей і частота обертання робочого колеса. Тому функціональну залежність (2) доцільно трансформувати також до виду

$$
Q^{1}=\psi\left(\alpha_{o}, n^{1}\right)
$$

Застосування залежностей у формі (4) актуально для малих гідроелектростанцій (ГЕС), які працюють в умовах природоохоронних обмежень на використання води стоку річки для виробництва електроенергї $[11,12]$, та для малих ГЕС на зворотних водах технологічних процесів [13].

Функціональні залежності (2), (4) можуть бути представлені у вигляді поверхні Кунса, Безье, Лагранжа, сплайну [8,9]. Зважаючи на успішне застосування кубічних сплайнів для апроксимації двопараметричних гідромеханічних характеристик турбін [14], подальше викладення буде грунтуватись на використанні сплайнфункцій, які описують поверхню, зокрема (4), в такий спосіб [6,7]:

$S_{3,3}^{i, j}\left(Q^{1}, \alpha_{0}, n^{1}\right)=\sum_{(\mathrm{m}, z)=0}^{3} k_{m, z}^{i, j}\left(\alpha_{0}-\alpha_{0 i}\right)^{m}\left(n^{1}-n_{j}^{1}\right)^{z},(5)$

де $\mathrm{S}$-сплайн-функція, $k$ - коефіцієнти сплайна.

Графічна інтерпретація (5), відповідно до вихідних даних на рис.1, показана на рис.2 (візуалізацію результатів в статті виконано М.Р. Ібрагімовою ). 


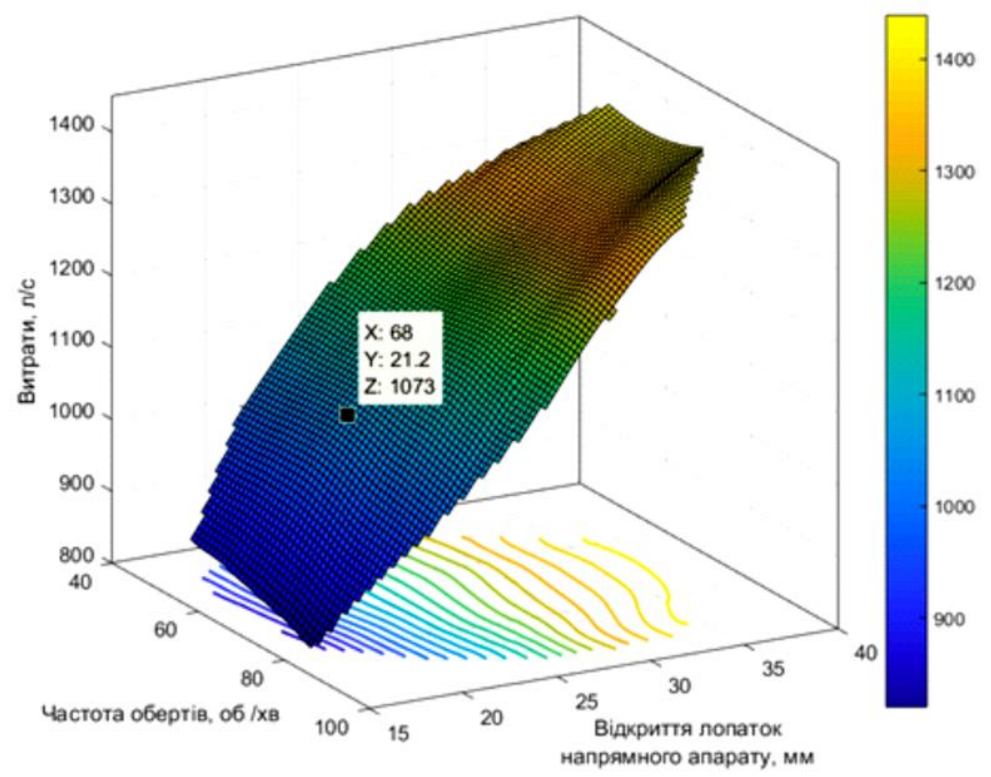

Рис. 2. Сплайн-апроксимація двопараметричної залежності $Q^{1}\left(\alpha_{0}, n^{1}\right)$ та її візуалізація неперервною поверхнею

Fig. 2. Spline approximation of one-parameter dependence $Q^{1}\left(\alpha_{0}, n^{1}\right)$ and it's visualization by a continuous surface

Тепер розглянемо замкнені криві на неперервною поверхнею показана на рис.3. Форма універсальній характеристиці, які являють собою поверхні випукла 3 наявністю екстремальних ізолінії сталого значення ККД у функції зведених значень ККД. Сукупність точок з найбільшими значень витрат $\left(Q^{l}\right)$ та обертів $\left(n^{l}\right)$. Ізолінії ККД екстремальними значеннями утворює криву також можуть бути представлені, 3 максімори поверхні $\eta_{\max }\left(\alpha_{0}, n^{1}\right)$, яка відповідає використанням (4), в координатах площини параметрів керування $\left(\alpha_{o}, n^{l}\right)$. Сплайнапроксимація сімейства ізоліній ККд діапазонах зміни параметрів керування (рис.3).

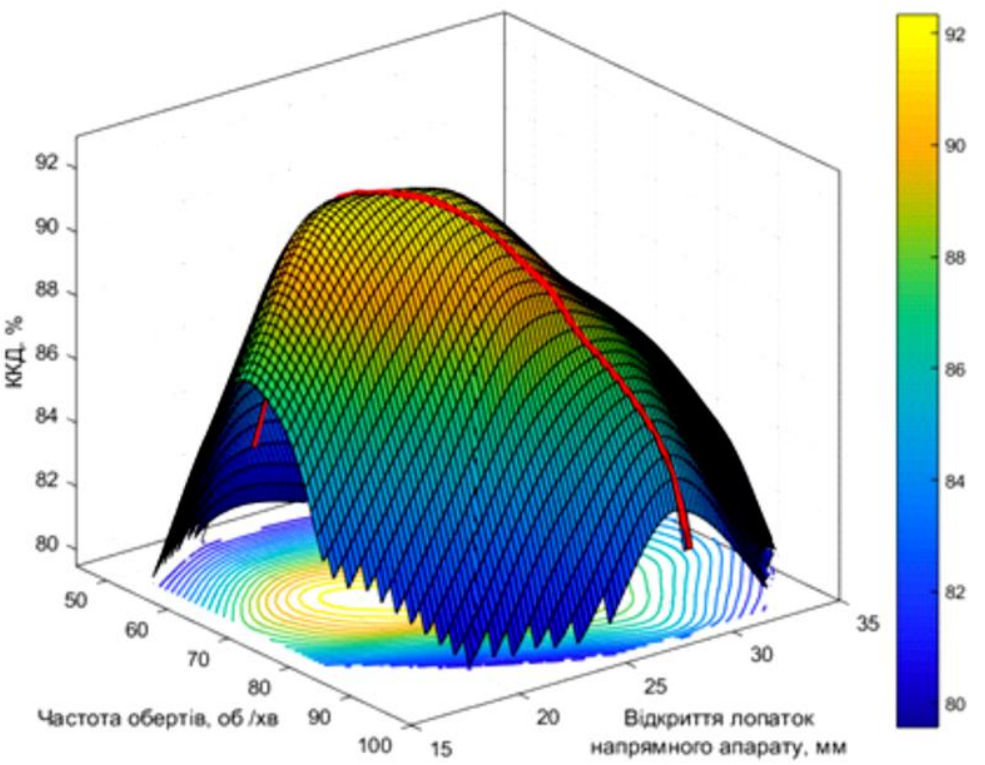

Рис. 3. Двопараметрична залежність $\eta\left(\alpha_{0}, n^{1}\right)$ з максіморою $\eta_{\max }\left(\alpha_{0}, n^{1}\right)$

Fig. 3. Two-parameter dependence $\eta\left(\alpha_{0}, n^{1}\right)$ with maximora $\eta_{\max }\left(\alpha_{0}, n^{1}\right)$ 
Проєкція просторової кривої максімори на площину параметрів керування $\left(\alpha, n^{l}\right)$ визначає функціональну залежність обертів від відкриття напрямного апарату $n^{1}\left(\alpha_{o}\right)$ при змінних витратах води для досягнення максимально можливого значення ККД (рис.4). Таким чином отримуємо закон керування 3 оптимальним співвідношенням обертів та відкриття напрямного апарату, який забезпечує максимально досяжну енергетичну ефективність гідротурбіни при змінних витратах води.

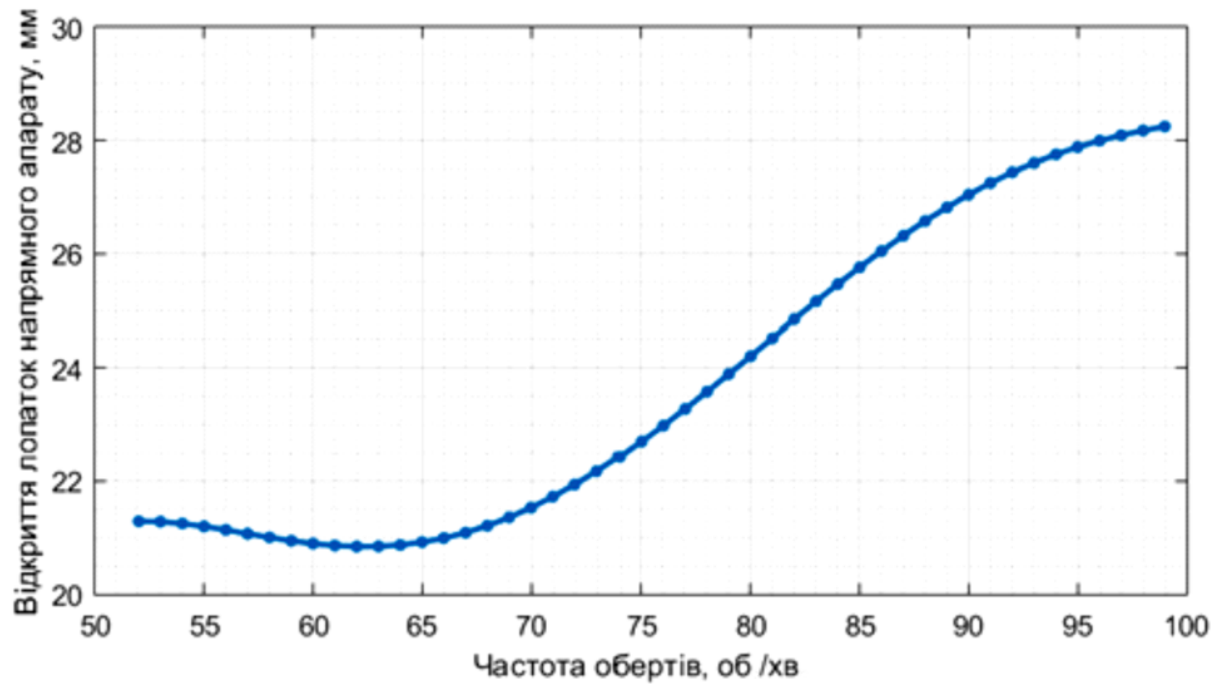

Рис. 4. Проєкція максімори поверхні на площину параметрів керування

Fig.4. Projection of the surface maxima on the plane of control parameters

У результаті проєкції просторової максімори на координатну площину відповідного параметра регулювання отримуємо однопараметричні залежності зміни ККД у процесі регулювання (рис.5).
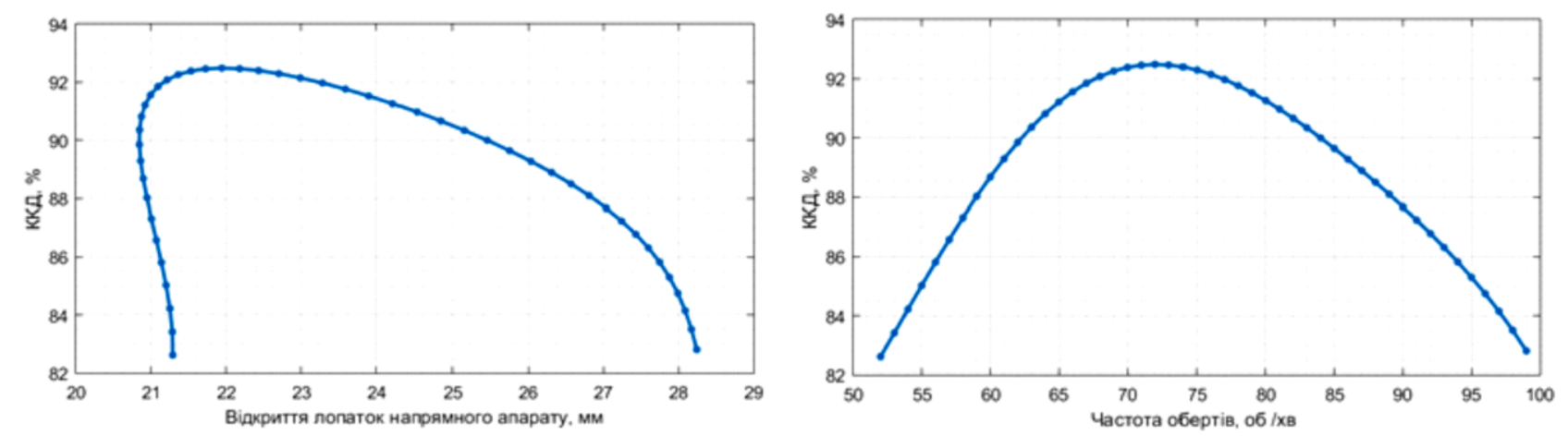

Рис. 5. Залежності ККД від параметрів регулювання

Fig. 5. Dependencies of efficiency on regulation parameters

Метод просторового перетину двох поверхонь може бути застосований для геометричного визначення сімейства необхідних для дослідження одно- та двопараметричних залежностей універсальної характеристики. Геометрична інтерпретація методу наведена на рис.6, де параметри представлені у відносних одиницях стосовно своїх номінальних значень. Відповідним чином можна отримати сімейство необхідних однопараметричних залежностей (рис.7). 

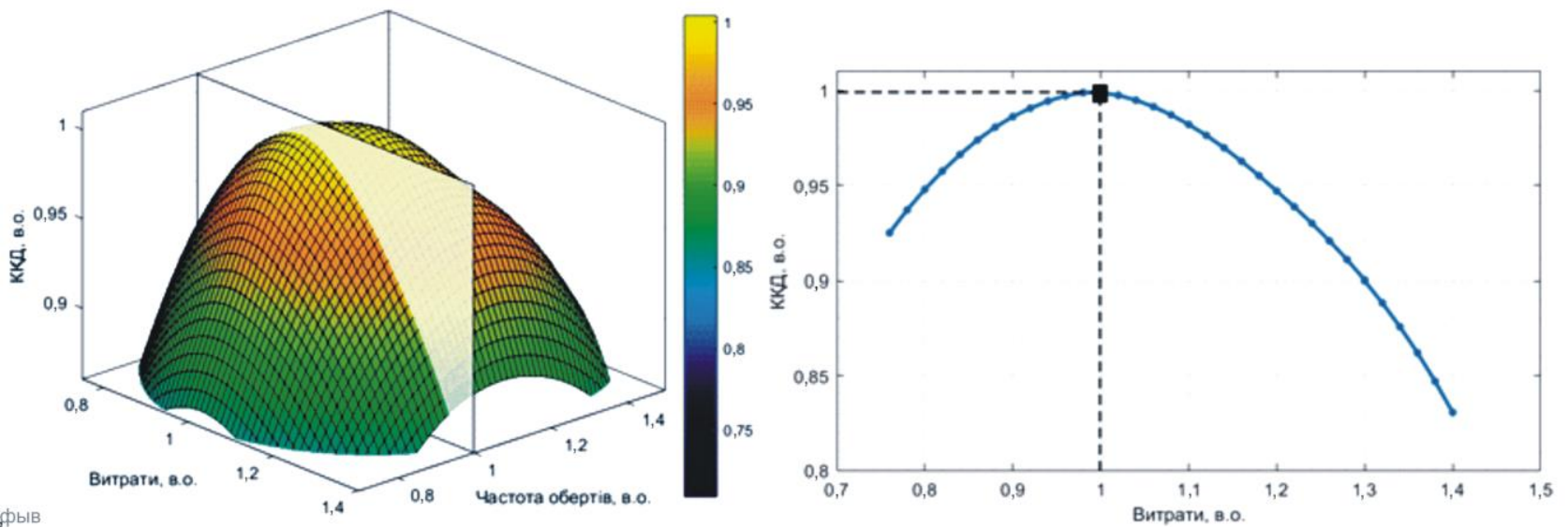

Рис. 6. Ілюстрація методу перетину двох поверхонь

Fig. 6. Illustration of the method of intersection of two surfaces

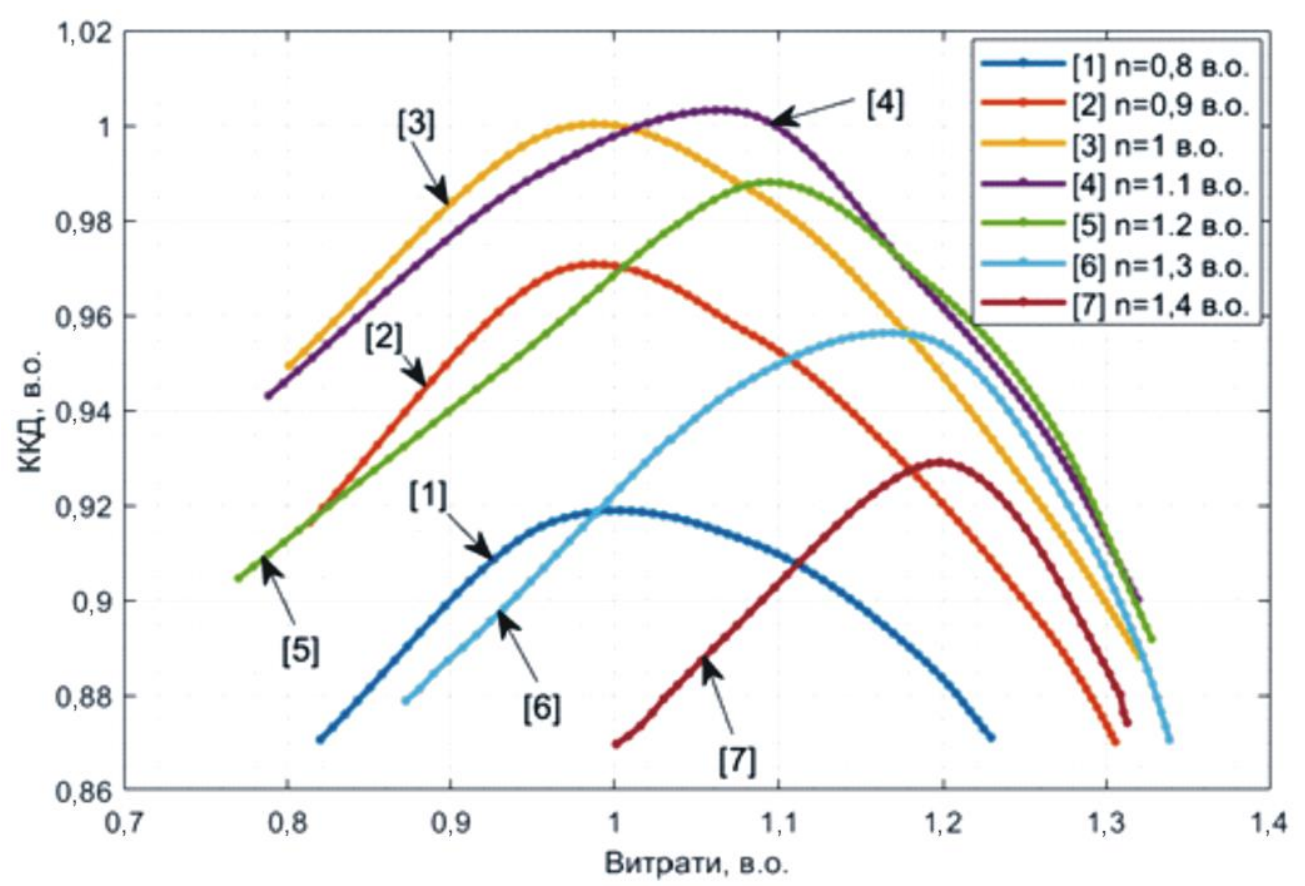

Рис. 7. Сімейство однопараметричних залежностей, отриманих методом перетину поверхонь

Fig. 7. The set of one-parameter dependences obtained by the method of intersection of surfaces

Аналіз результатів. Використання зображених на площині, то сімейство однорідних вихідної універсальної характеристики в розімкнених ліній (відкриття напрямного апарату, розрахункових дослідженнях режимів роботи кут повороту лопатей робочого колеса) можна гідротурбіни потребує іiї представлення інтерпретувати твірними відповідної поверхні, а числовими масивами даних. Автоматизація сімейство замкнених ліній - контурами перетину розрахункових досліджень може бути реалізована поверхні ККД горизонтальними площинами. Для шляхом інтерпретації числових масивів 3 математичного аналізу та візуалізації зазначених дискретними змінними деякою неперервною поверхонь доцільно застосування сплайнів на гладкою функцією (сплайном). Оскільки основі двопараметричних функцій, що надають універсальна характеристика гідротурбіни являє можливості визначення положення довільної собою сукупність розімкнених та замкнених ліній, точки поверхні, коли координатна сітка 
нерівномірна. В тривимірній графіці використовуються переважно кубічні сплайни, які дозволяють реалізувати процедуру з'єднання двох різних сплайнів із забезпеченням неперервності першої похідної для отримання гладкої складної поверхні (принагідно зазначимо, що термін «тривимірна графіка» означає візуалізацію тривимірних об'єктів на двовимірній площині монітора).

Сучасні пакети прикладних програм реалізують апроксимацію поверхні кубічними сплайнами з неперервними похідними функції до другого порядку включно та крайовими умовами першого і третього роду [15], проте проміжні результати у вигляді матриць коефіцієнтів сплайну зазвичай недосяжні. Ця обставина значно зменшує ефективність проведення багатоваріантних розрахункових досліджень експлуатаційних режимів роботи, перехідних процесів пуску i зупинення гідроагрегатів, оскільки основні затрати часу при апроксимації необхідні для обчислення коефіцієнтів сплайну. Особливо актуально знання коефіцієнтів сплайну для створення систем керування енергоефективними режимами роботи гідроагрегатів при одночасній зміні відкриття напрямного апарату й частоти обертання турбіни (рис.3, 4). Цей режим роботи може бути досягнутий шляхом застосування як генератора електричної машини подвійного живлення 3 векторним способом управління, який дозволяє одночасне незалежне регулювання як частоти, так i моменту генератора [16]. При використанні цього способу математичні моделі гідротурбіни та генератора являють собою складові системи управління, $і$ затрати часу на їх реалізацію істотно впливають на швидкодію регулювання. Тому для задач керування необхідно окремо попередньо розраховувати коефіцієнти сплайну і формувати необхідні двовимірні масиви, растри або матриці. Обчислення значень коефіцієнтів на нерівномірній сітці вихідних параметрів потребує формування i розв'язку відповідної системи алгебраїчних рівнянь [6,7].

Оскільки універсальна характеристика представляється сукупністю достатньо гладких кривих, то для іiі апроксимації можуть бути застосовані й кубічні сплайни 3 неперервною першою похідною функції та крайовими умовами першого роду. В цьому разі визначення коефіцієнтів сплайну значно спрощується в результаті застосування рівномірної сітки параметрів регулювання i обчислення коефіцієнтів сплайну прямим розрахунком за рекурентними співвідношеннями на основі вихідних даних [17]. Отже, доцільний алгоритм визначення коефіцієнтів сплайну двопараметричної залежності універсальної характеристики, заданої на нерівномірній сітці параметрів, може полягати у проведенні апроксимації на основі існуючого пакету прикладних програм з наступним перерахунком на рівномірну сітку i формуванні необхідної матриці коефіцієнтів за рекурентними співвідношеннями.

Висновки. 1. Розроблено методичні положення визначення енергоефективного режиму роботи пропелерних та радіально-осьових гідротурбін при змінних витратах води та частоти обертання. Положення грунтуються на застосуванні методів інженерної геометрії для апроксимації універсальної характеристики турбіни у формі поверхні тривимірного геометричного тіла та визначення максімори 
поверхні, яка характеризує оптимальну функціональну залежність між відкриттям напрямного апарату та частотою обертання i забезпечує найбільшу енергетичну ефективність процесу перетворення гідроенергетичного потенціалу водотоку в механічну енергію обертового руху турбіни.

2. Запропоновано алгоритм розрахунку коефіцієнтів апроксимаційних кубічних сплайнфункцій універсальної характеристики гідротурбіни для визначення та реалізації законів керування енергоефективними режимами роботи гідроагрегатів при одночасній зміні двох параметрів керування. Алгоритм полягає в апроксимації вихідної універсальної характеристики гідротурбіни на рівномірну сітку параметрів керування 3 подальшим прямим розрахунком коефіцієнтів сплайн-функцій за рекурентними співвідношеннями.

1. ДСТУ 2842-94. Турбіни гідравлічні. Терміни та визначення. Київ. Держстандарт України. 1995. 35 с.

2. Кривченко Г.И. Гидравлические машины: Турбины и насосы. Учебник для вузов. М. Энергия. 1978. $320 \mathrm{c}$.

3. Щавелев Д.С. Гидроэнергетические установки. Л. Энергоиздат. $1981.520 \mathrm{c.}$

4. Фокс А, Пратт М. Вычислительная геометрия. Применение в проектировании и на производстве. М. Мир. 1982.304 c.

5. Препарата Ф., Шеймос М. Вычислительная геометрия. Введение. М. Мир. 1989. 478 с.

6. Завьялов Ю.С., Леус В.А., Скороспелов В.А. Сплайны в инженерной геометрии. М. Машиностроение. 1985. 224c.

7. Квасов Б.И. Методы изогеометрической аппроксимации сплайнами. М. Физматлит. 2006. 360 с.

8. Голованов Н.Н. Геометрическое моделирование. М. Физматлит. 2002. 472 с.
9. Никулин E.A. Компьютерная геометрия и алгоритмы машинной графики. СПб. БХВ-Петербург. $2003.560 \mathrm{c}$.

10. Рябинин К.В. Вычислительная геометрия и алгоритмы компьютерной графики. Работа с 3D-графикой средствами OpenGL. Пермь. Перм. гос. нац. исслед. ун-т. 2017. $100 \mathrm{c}$.

11. Васько П.Ф., Мороз А.В. Законодательные стимулы и природоохранные ограничения использования гидроэнергетических ресурсов малых рек Украины. Альтернативная энергетика и экология (ISJAEE). 2014. № 15. C. 82-92.

12. Васько П.Ф., Мороз А.В., Бриль А.О., Iбрагімова M.P. Екологічні аспекти розвитку гідроенергетики в Україні. Відновлювана енергетика. 2018. № 2. C. 57-69.

13. Бриль А.О., Васько П.Ф., Мороз А.В. Нормативно-правові аспекти використання в Україні гідроенергетичного потенціалу зворотних вод технологічних процесів за “зеленим” тарифом на генеровану електроенергію. Відновлювана енергетика. 2021. № 1. С. 59-69.

14. Васько П.Ф. Повышение энергетической эффективности малых гидроэлектростанций путем применения переменной частоты вращения гидроагрегатов. Альтернативная энергетика и экология (ISJAEE). 2011. № 8. C. 115-132.

15. Мороз А.В. 3D моделювання гідромеханічних характеристик малих гідроелектростанцій. Відновлювана енергетика. 2020. № 2. С. 70-79.

16. Шаповал І.А., Михальський В.М., Артеменко М.Ю., Полішук С.Й., Чопик В.В. Комплекси генерування електроенергії 3 функціями компенсації реактивної потужності та активної фільтрації на базі машини подвійного живлення. Монографія. Київ. Інститутелектродинаміки НАН України. 2020. 241 с.

\section{7. Васько П.Ф., Васько В.П., Озорін Д.Ф.}

Двовимірна сплайн-апроксимація гідромеханічних та енергетичних характеристик гідромашин в режимах насостурбіна за змінної частоти обертання. Відновлювана енергетика. 2010. № 3. С. 64-72. 


\section{REFERENCE}

1. DSTU 2842-94. Turbiny hidravlichni. Terminy ta vyznachennia. [Hydraulic turbines. Terms and definitions]. Kyiv. State Standard of Ukraine. 1995. 35 p. [in Ukrainian].

2. Kryvchenko H.Y. Gidravlicheskiye mashiny: Turbiny i nasosy. [Hydraulic machines: Turbines and pumps]. Textbook for universities. M. Energiya. 1978. 320 p [in Russian].

3. Shchavelev D.S. Gidroenergeticheskiye ustanovki. [Hydropower installation]. L. Energoizdat. 1981. 520 p. [in Russian].

4. Foks A. Pratt M. Vychislitelnaya geometriya Primeneniye v proyektirovanii i na proizvodstve. [Computational geometry. Application in design and production]. M. Mir. 1982. 304 p. [in Russian].

5. Preparata F., Sheymos $M$. Vychislitelnaya geometriya. [Computational geometry. Introduction]. Vvedeniye. Moscow. Mir. 1989. 478 p. [in Russian].

6. Zavialov Yu.S., Leus V.A., Skorospelov V.A. Splayny $\mathrm{v}$ inzhenernoy geometrii. [Splines in engineering geometry]. M. Mashinostroyeniye. 1985. 224 p. [in Russian].

7. Kvasov B.I. Metody izogeometricheskoy approksimatsii splaynami. [Isogeometric spline approximation methods]. Moscow. Fizmatlit. 2006. 360 p. [in Russian].

8. Golovanov N.N. Geometricheskoye modelirovaniye. [Geometric modeling]. Moscow. Fizmatlit. 2002. 472 p. [in Russian].

9. Nikulin E.A. Kompyuternaya geometriya i algoritmy mashinnoy grafiki. [Computer geometry and computer graphics algorithms]. SPb. BKhV-Peterburg. 2003. 560 p. [in Russian].

10. Ryabinin K.V. Vychislitelnaya geometriya algoritmy kompyuternoy grafiki. Rabota s 3D-grafikoy sredstvami OpenGL. [Computational geometry and computer graphics algorithms. Working with 3D graphics by means OpenGL]. Perm. Perm. gos. nats. issled. un-t. 2017. 100 p [in Russian].

11. Vasko P.F., Moroz A.V. Zakonodatelnye stimuly i prirodookhrannye ogranicheniya ispolzovaniya gidroenergeticheskikh resursov malykh rek Ukrainy. [Legislative Incentives and Environmental Restrictions on the Use of Hydropower Resources of Small Rivers of Ukraine].
Alternativnaya energetika i ekologiya (ISJAEE). 2014. No. 15. Pp. 82-92. [in Russian]

12. Bryl A.A., Vasko P.F., Moroz A.V., Ibragimova M.R. Ekolohichni aspekty rozvytku hidroenerhetyky v Ukrayini. [Ecological aspects of hydropower development in Ukraine]. Vidnovluvana energetika. 2018. No. 2. Pp. 57-69. [in Ukrainian].

13. Bryl A.O., Vasko P.F., Moroz A.V. Normatyvnopravovi aspekty vykorystannia $\mathrm{v}$ Ukraini hidroenerhetychnoho potentsialu zvorotnykh vod tekhnolohichnykh protsesiv za "zelenym" taryfom na henerovanu elektroenerhiiu. [Regulatory aspects of use hydroenergy potential in ukraine of return watersof technological processes by «green» tariff at the generated electricity]. Vidnovliuvana enerhetyka. 2021. No. 1. Pp. 59-69. [in Ukrainian].

14. Vasko P.F. Povysheniye energeticheskoy effektivnosti malyk hgidroelektrostantsiy putem primeneniya peremennoy chastoty vrashcheniya gidroagregatov. [Increasing power efficiency of small hydro-power plants by implementing variable rotation frequency of hydraulic units]. Alternativnaya energetika i ekologiya (ISJAEE). 2011. No. 8. Pp. 115-132. [in Russian].

15. Moroz A.V. 3D modeliuvannia hidromekhanichnykh kharakterystyk malykh hidroelektrostantsii. [3D simulation of hydromechanical characteristics of small hydropower plants]. Vidnovliuvana enerhetyka. 2020. No. 2. Pp. 70-79. [in Ukrainian].

16. Shapoval I.A., Mykhalskyi V.M., Artemenko M.Iu., Polishchuk S.I., Chopyk V.V. Kompleksy heneruvannia elektroenerhii z funktsiiamy kompensatsii reaktyvnoi potuzhnosti ta aktyvnoi filtratsii na bazi mashyny podviinoho zhyvlennia. [Power generation complexes with reactive power compensation and active filtration functions based on dual power supply machine]. Monohrafiia. Kyiv. Institute of Electrodynamics NAS of Ukrainy. 2020. 241 p. [in Ukrainian].

17. Vasko P.F., Vasko V.P., Ozorin D.F. Dvovymirna splain-aproksymatsiia hidromekhanichnykh ta enerhetychnykh kharakterystyk hidromashyn $\mathrm{v}$ rezhymakh nasos-turbina za zminnoi chastoty obertannia. [Two-dimensional approximation of hydromechanical and energy characteristics of hydraulic machines in pump-turbine modes at variable speed]. Vidnovluvana energetika. 2010. No. 3. Pp. 64-72. [in Ukrainian]. 